\title{
Chapter 5 \\ The Dynamics of Opportunity in America: A Working Framework
}

\author{
Henry Braun
}

\begin{abstract}
Since its founding, America has been seen as a land of opportunity, where an individual with skills who was willing to work hard could achieve success and expect his children to do even better. Today we live in turbulent times: A tsunami of change is washing over us, driven by forces operating at multiple levels that have not only led to almost unprecedented inequalities in income and wealth, but also have dramatically restructured the economy and changed the landscape of work. Having sufficient amounts of relevant human and social capital are more critical than ever-and too many Americans are finding they are not equipped to succeed as workers and citizens. Growing inequities in access to opportunities to develop needed capital, strongly linked to socioeconomic status should be cause for grave concern. This chapter presents a framework - gates, gaps, and gradients - that can facilitate understanding of both the dynamics governing the distribution of access to opportunity across the developmental lifespan and the implications of those dynamics for intragenerational and intergenerational mobility. Further, it indicates in broad strokes how this nation can begin to broaden opportunity in order to revitalize the American Dream for the twenty-first century.
\end{abstract}

Keywords Opportunity • Globalization • Technology • Human capital • Wages • Educational attainment $\bullet$ Skills $\bullet$ Intergenerational mobility $\bullet$ Socioeconomic status $(\mathrm{SES}) \bullet$ Unmarried mothers • Unemployment

\section{Introduction}

We live in turbulent times - economically, technologically, socially, and politically. A tsunami of change is washing over us, driven by forces operating at all levels: global, national, regional, and local. Some of these forces, such as globalization and technology, are supranational. Some, such as fiscal and trade policy, are decided at

\footnotetext{
H. Braun ( $\square)$

Lynch School of Education, Boston College, Chestnut Hill, MA 02467, USA

I. Kirsch, H. Braun (eds.), The Dynamics of Opportunity in America, 
the national level. Others, such as education and health policies, are the result of a combination of national and state actions. Yet others, such as changes in the demographics of neighborhoods, are influenced by forces at all levels, such as international migration patterns, as well as by local laws and regulations adopted to achieve certain policy objectives or to accommodate the interests of various stakeholders.

Even prior to the Great Recession, stable employment and guaranteed retirement were pledged to fewer and fewer workers. Today, the nation is experiencing not only ongoing "creative destruction" of firms (and of jobs within firms) but also threats to both public and private pensions. Correspondingly, increasing numbers of individuals are either "under water" or confronting that prospect. Although some are able to ride the wave and prosper, they, too, face greater uncertainties. Indeed, for almost everyone, this is the Age of Anxiety.

That justifiable anxiety is, in part, a consequence of increasing inequality in both income and wealth driven by trends in labor and capital markets, as well as by differences in opportunities to accumulate relevant human capital. Arguably, today's differences will lead to even greater divergence in opportunities in the future. The implications of such a self-reinforcing, multigenerational cycle-for the economy, for society, and for our democratic polity — are a matter of current debate. ${ }^{1} \mathrm{I}$ believe that such a prospect is one we cannot afford to ignore. As Nobel Laureate Joseph Stiglitz argues, "An economic and political system that does not deliver for most citizens is one that is not sustainable in the long run. Eventually, faith in democracy and the market economy will erode, and the legitimacy of existing institutions and arrangements will be called into question. ${ }^{2}$

This is certainly not the first time in our country's history that we face great difficulties. In the past, however, there were two beliefs, held by many, that helped to sustain and inspire us to meet the challenges. The first was American exceptionalism-America was unlike (and better than) other countries, truly a light unto the nations. The second was that the U.S. was a land of unprecedented opportunity-no matter their circumstances at birth, individuals could realistically expect to improve themselves through education, hard work, and persistence, and more importantly, their children could aspire to do even better.

These beliefs are harder to maintain today. World events have shaken our belief in American exceptionalism, and reams of statistics-not to mention the experiences of tens of millions of individuals - cast doubt on meaningful opportunity in America being available to all. Indeed, surveys show that many older persons, especially parents, believe that the next generation will not do as well

\footnotetext{
${ }^{1}$ Stiglitz 2012; Cowen 2013.

${ }^{2}$ Joseph Stiglitz, "Climate Change and Poverty Have Not Gone Away," Guardian, January 7, 2013, http://www.theguardian.com/business/2013/jan/07/climate-change-poverty-inequality.
} 
as they have-and even fewer adults consider themselves members of the middle class. ${ }^{3}$

Historically, differences in opportunity were associated with race and, indeed, this was the prime motivation for the Great Society legislation pursued by President Lyndon Johnson in the mid-1960s. Although differences by race and ethnicity persist and remain substantial, there is considerable evidence that differences (say, in test scores) by income are now larger than those by race. Moreover, differences by income within a race/ethnicity category are also quite striking (Reardon 2011; Murray 2012). As will be demonstrated in what follows, individual differences in opportunity result in differences in individuals' levels of preparedness to successfully meet the demands of adult life-as workers, citizens and, for most, parents. That level of preparedness is often signified by the term human capital. This chapter focuses on human capital: what it is, how it develops and is accumulated, what is happening to its distribution across the U.S. population, and some possible consequences if current trends continue.

Before diving in, let's look at some data to give us a sense of the state of inequality in America. Following the old adage that a picture is worth a thousand words, we begin with some graphs. Figure 5.1 shows the percentile trajectories for wages and salaries from 1961 to 2000. For about 30 years after World War II, the relationships among the trajectories remained fairly stable, that is, greater prosperity was generally shared. After 1975, and certainly after 1980, the income trajectories began to diverge, quite dramatically. What is especially noteworthy is how the top percentiles

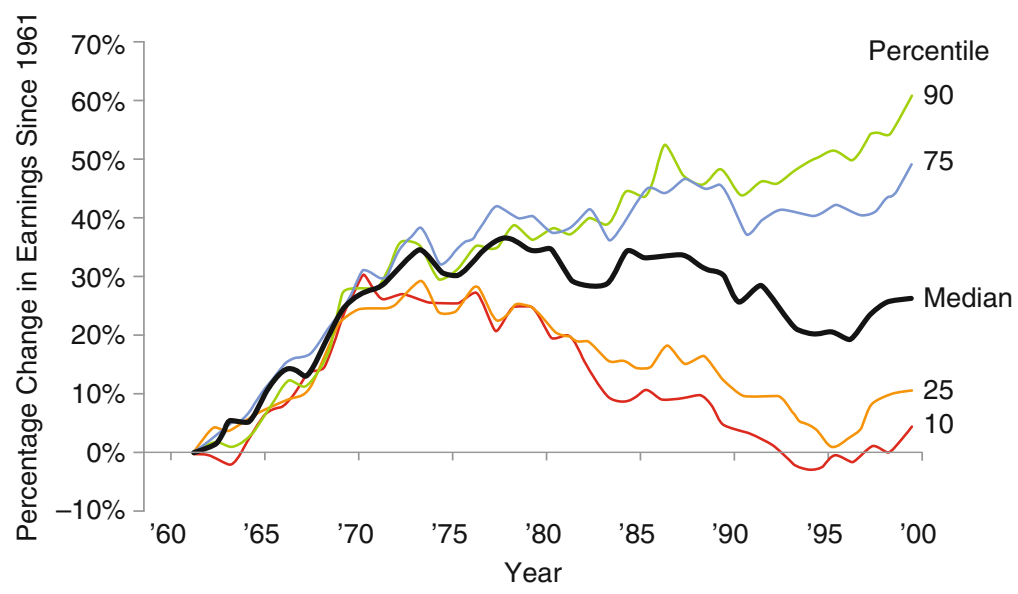

Fig. 5.1 Distribution of real wage and salary earnings for full-year, full-time males workers aged 18-64 as compared to 1961-2000 (Used by permission of The Aspen Institute)

${ }^{3}$ Leslie McCall, "Political and Policy Responses to Problems of Inequality: Past, Present and Future" (unpublished presentation, Opportunity in America advisory panel meeting, June 2014). 


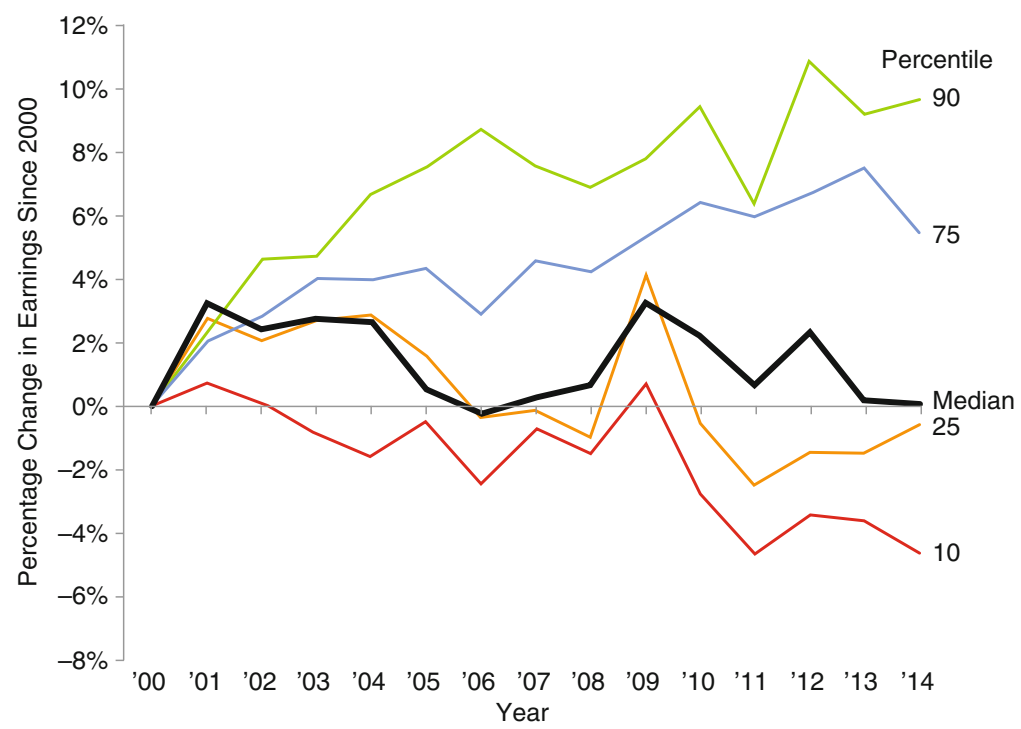

Fig. 5.2 Distribution of real wage and salary earnings for full-year, full-time male workers aged 16 and over, as compared to 2000 (Source: Author's tabulations of the Current Population Survey)

have pulled away from the rest-a striking manifestation of increasing inequality. ${ }^{4}$ Figure 5.2 presents an analogous picture but employs 2000 as a new starting point. Clearly the divergence in earnings between the higher and lower percentiles has continued through 2014. Putting the two figures together yields a disturbing picture of increasing inequality.

Figure 5.3, which offers a more focused view of this phenomenon, displays the cumulative change (1979-2010) in real annual wages by income group, defined by percentiles of the income distribution. ${ }^{5}$ Evidently, the increases garnered by the top $1 \%$ dwarf those in the 95th-99th and the 90th-95th percent categories. But these are still more than double the $15 \%$ gain of the rest (the "bottom" $90 \%$ ) (Thompson 2012). The divergence is even more striking for changes in total annual household income (i.e., including both capital gains and income transfers)—and more striking still if one considers household wealth or shares of the stock market (Piketty 2014; for a quicker look, see Thompson 2012). ${ }^{6}$ At the same time, some economists argue

\footnotetext{
${ }^{4}$ Tabulations by Professor David Ellwood, Harvard University.

${ }^{5}$ Economic Policy Institute (State of Working America). It is important to understand that this graph does not follow specific people over time but, rather, is constructed anew each year. Thus, it doesn't tell us anything about the (relative) income mobility or immobility of particular individuals.

${ }^{6}$ Data from the Congressional Budget Office shows that the cumulative growth in average after-tax income (sum of market income and government transfers minus federal tax liabilities) did not vary much across the bottom four quintiles.
} 


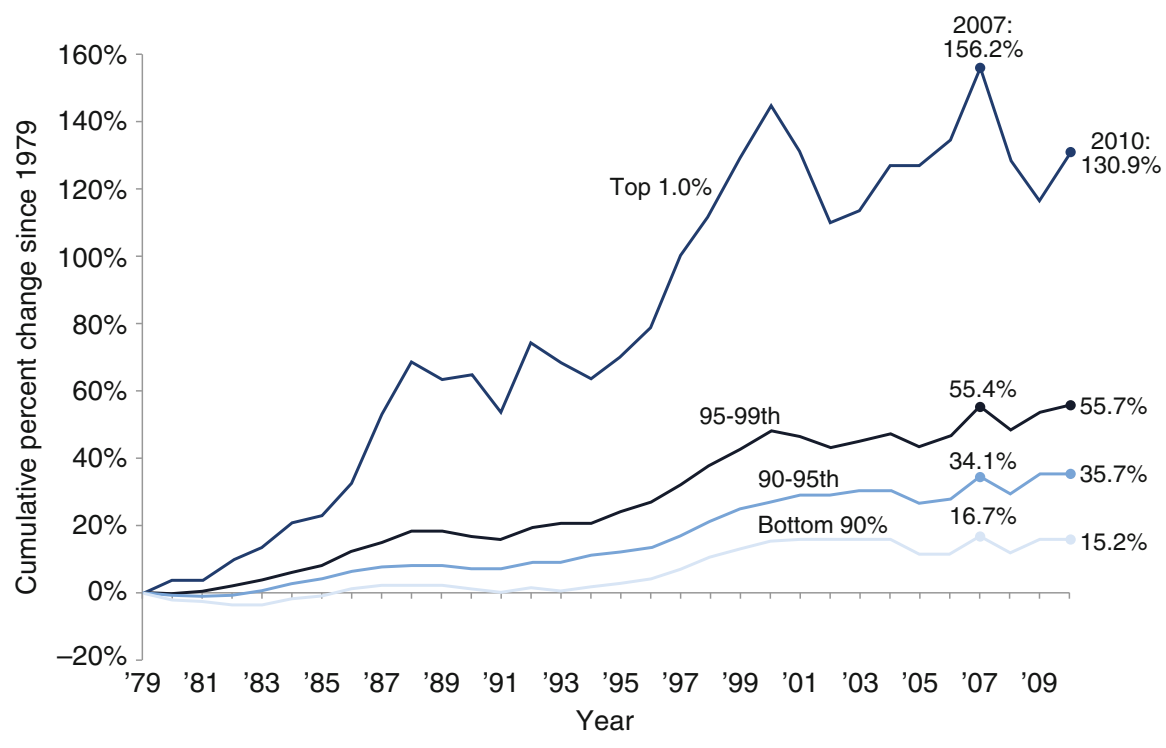

Fig. 5.3 Cumulative change in real annual wages, by wage group, 1979-2010 (Economic Policy Institute, 2012, "Cumulative Change in Real Annual Wages, by Wage Group, 1979-2010", The State of Working America, Washington, DC: Economic Policy Institute, Aug. 22, 2012, www. stateofworkingamerica.org/jobs/figure4H)

that focusing on the trajectory of the " $1 \%$ " is misguided, at least with respect to addressing the broader issues of inequality (Mankiw 2013). ${ }^{7}$

Figure 5.4 displays the 50-year trajectories of real wages for different levels of educational attainment, separately for men and women (Autor 2014; see also Acemoglu and Autor 2012, Fig. 3). Although there are some differences between males and females, in general, individuals with higher levels of attainment have done well, while those at the lowest levels have either stagnated (high school diploma) or even lost ground (less than a high school diploma). Who are the individuals in that last category? Table 5.1 offers one answer. It displays the probability of individuals lacking a high school diploma or GED as a function of their family income and their Armed Services Vocational Aptitude Battery (ASVAB) score, a composite measure of developed skills. ${ }^{8}$ More than $35 \%$ of individuals coming from poor families with ASVAB scores in the lowest quintile fall in this category of attainment, with the percentages falling with increasing family income and dramatically so with higher ASVAB scores.

\footnotetext{
${ }^{7}$ Tyler Cowen,“ It's Not the Inequality; It's the Immobility.” New York Times, April 5, 2015 , http://www.nytimes.com/2015/04/05/upshot/its-not-the-inequality-its-the-immobility.html? $a b t=0002 \& a b g=1$.

${ }^{8}$ Data compiled by the Center for Labor Market Studies, Northeastern University. For more information see http://official-asvab.com/index.htm.
} 
a

Real weekly earnings relative to 1963 (men)

2.0

1.8

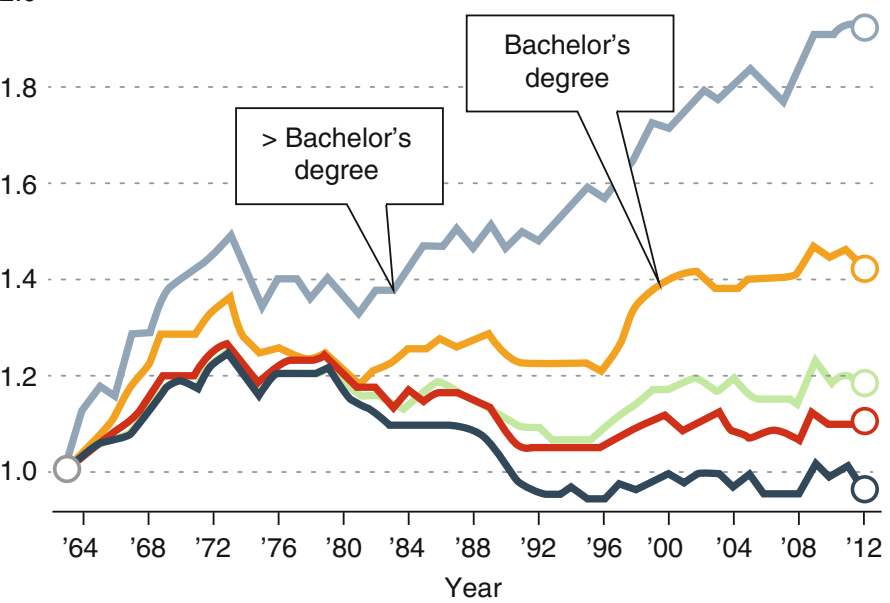

b

Real weekly earnings relative to 1963 (women)

2.0

Some college

1.8

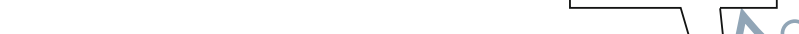

1.6

\section{High school} dropout

1.4

High school graduate

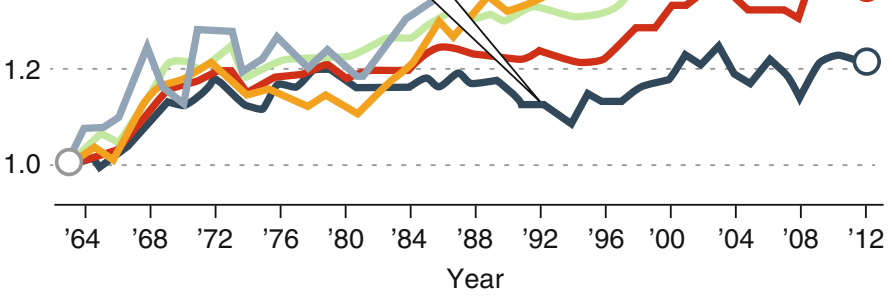

Fig. 5.4 Changes in real wage levels of full-time U.S. workers by sex and education, 1963-2012 (Reproduced from Autor 2014) 
The last graph in this series, Fig. 5.5, compares the problem-solving skills of American adults (ages 16-65) to those of other developed countries. Comparisons are displayed for two age classes. This is also very striking: For the oldest age class (55-64), the U.S. is at the top, but for the youngest age class (16-24), the U.S. is at the bottom (OECD 2013, Fig. 3.3).

What do these pictures tell us? Figures 5.1, 5.2 and 5.3 demonstrate that rising income inequality is real. Even when government benefits are taken into account there is still a widening gap between the bottom $50 \%$ and the top $10 \%$, and even more so if attention focuses on the top $1 \%$ or, especially, the top $0.1 \%$. Figure 5.4 and Table 5.1 together show that income inequality is strongly related to the amount

Table 5.1 Percent of 24- to 28-year-old adults in the U.S. in 2008 without a high school diploma or GED by ASVAB test score quintile and family's income in their teenaged years in 1997 (Andrew Sum 2014, presentation to Opportunity in America panel)

\begin{tabular}{l|l|l|l|l|l|l}
\hline \multirow{2}{*}{ Family income } & $(\mathrm{A})$ & $(\mathrm{B})$ & $(\mathrm{C})$ & $(\mathrm{D})$ & $(\mathrm{E})$ & $(\mathrm{F})$ \\
\cline { 2 - 8 } Poor & Bottom & Second & Middle & Fourth & Top & All \\
\hline $1-2 *$ poor & 35.9 & 15.4 & 10.6 & 4.7 & 0 & 22.9 \\
\hline $2-3 *$ poor & 30.0 & 11.1 & 6.5 & 2.3 & 4.3 & 15.4 \\
\hline $3-4 *$ poor & 19.8 & 8.4 & 5.2 & 1.2 & 0 & 6.7 \\
\hline 4 or more * poor & 19.0 & 5.8 & 7.4 & 1.2 & 0 & 4.0 \\
\hline All & 16.3 & 1.7 & .6 & 0 & 0 & 2.1 \\
\hline & 28.3 & 8.2 & 3.7 & 1.5 & .5 & \\
\hline
\end{tabular}

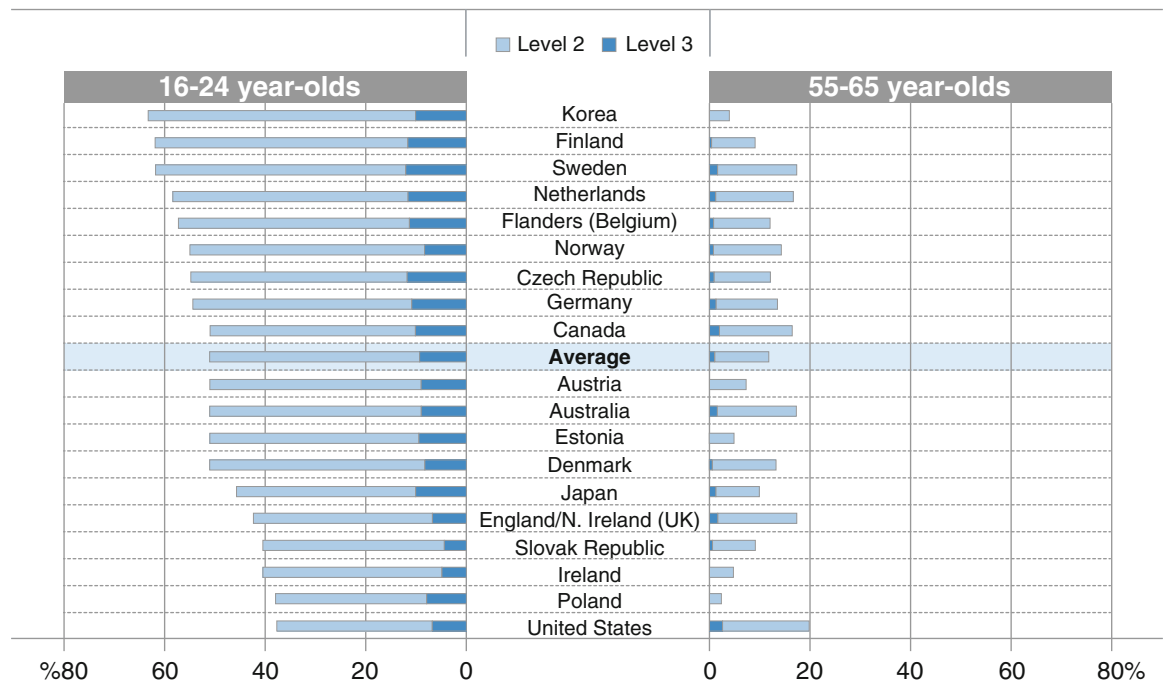

Fig. 5.5 Problem-solving proficiency among younger adults (age 16-24) and older adults (age 55-65) (OECD 2013)

Percentage of adults aged 16-24 and 55-65 scoring at level 2 or 3 in problem solving in technologyrich environments 
of education achieved and that those with weak skills and coming from poor families are likely to fall in the lowest category of attainment. ${ }^{9}$ It is reasonable to conclude that individuals with low skills are unlikely to earn a good wage while those with high skills have an excellent chance of doing so. In point of fact, there are now millions of individuals with low skills confronting poor job prospects.

Figure 5.5 signals America's relative decline. Today's young adults may not be less literate than their elders (and may well be more proficient with technology), but other countries have charged ahead so that too many of our young adults are not competitive in the global marketplace and, more and more, the global marketplace influences what happens in towns and cities across America. Unfortunately, the problem is not confined to the youngest cohort. As Kevin Carey of the New America Foundation has pointed out, comparisons of literacy skills among 25 to 29-year-olds who are college graduates show that Americans again fall well below the Organisation for Economic Co-operation and Development average. ${ }^{10}$ Similar findings hold for numeracy skills (see Fig. 8 of Goodman, Sands, and Coley 2015).

There is a growing consensus that current trends, if left unchecked, pose a serious threat not only to the American Dream, but to the American way of life (Stiglitz 2012; Noah 2013). If that is the case, we must understand these forces and their interactions if we are to have even a possibility of countering their effects. At the same time, given the multiplicity of factors and the range of dynamics among them, it would be naïve to believe that there is a simple fix such as to just "improve education" or "make the income tax more progressive"; rather, it is surely necessary to undertake a broad set of strategies that are systematic, systemic, and sustained. This will be neither simple nor easy.

The chief purpose of this chapter, undertaken under the auspices of the Opportunity in America project and funded by Educational Testing Service, is to present a framework that can help us to understand both the dynamics governing the distribution of access to opportunity in America and the implications of those dynamics for intragenerational and intergenerational mobility. It offers some of the relevant evidence and constitutes an initial foray into an exceedingly complex and controversial topic. The ultimate goal of the project is to contribute to a constructive public debate on the implications of increasing inequality and social stratification, however measured, and how we can dramatically expand opportunity in order to revitalize the American Dream for the 21 st century.

\footnotetext{
${ }^{9}$ It appears that differences in educational attainment better account for differences in income below the median than they do above the median - especially differences within the top quintile.

${ }^{10}$ Kevin Carey, "Americans Think We Have the World's Best Colleges. We Don't," New York Times, June 28, 2014, http://www.nytimes.com/2014/06/29/upshot/americans-think-we-have-theworlds-best-colleges-we-dont.html.
} 


\section{What Is Opportunity?}

Opportunity is defined by Merriam-Webster as a favorable juncture of circumstances. For our purposes it can be thought of as the set of paths by which a child's potential develops over time into the broad set of skills, competencies, and dispositions (i.e., the human capital) that will enable him or her to successfully navigate adult life. By inequality of opportunity we mean that the paths for some children present relatively few obstacles to their developmental trajectories; for others, there are many obstacles and, consequently, they are less likely to be able to amass needed human capital. ${ }^{11}$

Not surprisingly, the path a child traverses is strongly related to his or her family's circumstances at birth and the early years that follow. In fact, the data show that those children born with substantial advantages are on track to accumulate a great deal of human capital and, consequently, are very unlikely to fall much below their beginnings, at least with respect to their relative standing on the income ladder. ${ }^{12}$ By contrast, those children born into pervasive disadvantage face great difficulties in accumulating human capital and are very unlikely to rise much above their beginnings with respect to their relative standing. ${ }^{13}$ As one recent study in Baltimore argues, an impoverished childhood casts a "long shadow" on adult outcomes (Alexander et al. 2014).

Of course there are anecdotes of children "beating the odds" and achieving great success despite an unpromising start. ${ }^{14}$ But the data indicate that they are the rare exception and not the rule. And we must ask: Do we want America to be a country where millions of children must be heroes in order to achieve a modicum of security and stability?

\footnotetext{
${ }^{11}$ Although the focus of this chapter is on the distribution of opportunities to develop human capital over the age span of $0-25$, there are also differential opportunities in adulthood to productively employ that human capital and continue to amass it through one's lifespan. The former is addressed in a later section on gradients. Relevant factors include general skill-labor market fit, workplace discrimination, and secular economic trends. The latter depends on the nature of employment, the availability and affordability of venues for education and training, and individual choice.

${ }^{12}$ As one reviewer pointed out, the typical child whose father earns $\$ 500,000$ at age 40 may, when he or she reaches age 40 , be earning only $\$ 300,000$. This would be a manifestation of regression to the mean. The child then may have lost ground on absolute mobility but very little on relative mobility.

${ }^{13}$ See for example, publications based on The Brookings Institution's Social Genome Project (Brookings Institution 2013). For a more positive outlook on the impact of sustained and systematic interventions, see Sawhill and Karpilow 2014.

${ }^{14}$ There is some empirical evidence that succeeding against the odds takes a physical and psychological toll that has consequences in later years. See Brody et al. (2013).
} 


\section{The Challenge}

Understanding the dynamics underlying current trends and patterns in the distribution of opportunity across income levels and social strata, as well as increasing income inequality and stagnant intergenerational mobility, is critical to formulating meaningful policy responses. ${ }^{15}$ This is an exceedingly difficult task, made more challenging because the forces in question have a wide range. They include such factors as global macroeconomic trends, the transmission from parents to children of advantage (or disadvantage) related to family characteristics and resources, and neighborhood environment. Adding to this challenge is that both inequality and intergenerational mobility have been defined in different ways and studied with different populations, sometimes yielding different results (Black and Devereux 2010; Blanden 2013).

We also must take into account personal responsibility-the choices that individuals make along their life path and the consequences of those choices. That is, success in accumulating human capital and, subsequently, in the labor market depends on not only having opportunities but also taking advantage of them (see Chap. 8). Finally, the statistical averages that are often cited, whether of cognitive skills or income, mask enormous variation by geographical location, race/ethnicity, and other factors. This variation must be taken into account not only in understanding inequality but also in formulating policy prescriptions.

In order to sort out and make some sense of the wealth of empirical research that has been carried out, it is helpful to have a framework that can structure a description of how a child's potential and family circumstances at birth, interacting over time with forces large and small, result in a young adult (say, age 25) who is more or less ready to take responsibility for his or her future and lead a life of accomplishment and fulfillment.

The framework we propose is captured by the three-part metaphor of gates, gaps, and gradients. The next section introduces this framework, which is then used to describe some of the factors that contribute to differences in opportunity and the resulting variation in accumulated human capital. The final section looks forward to some policy actions that could counter current trends.

\section{The Framework: Gates/Gaps/Gradients}

The first element of the framework is Gates, a metaphor for how opportunity in America is increasingly determined by income, wealth, and socioeconomic status (SES), as well as by race/ethnicity. From birth to, say, age 25, individuals

\footnotetext{
${ }^{15}$ Intergenerational mobility (IGM) is a measure of the probability that a child with parents at one level in society will, as an adult, reside in a different level-higher or lower. The most commonly used scales are income, years of education, and socioeconomic status. Economists sometimes use the term intergenerational elasticity (IGE), which is the opposite of IGM.
} 
accumulate the human capital, broadly conceived, that will play a critical role in their adult outcomes. The dimensions of human capital include a variety of cognitive and noncognitive skills, as well as dispositions, experiences, and flexibility (see Keeley 2007; Pellegrino and Hilton 2012). At each stage of development, the gates represent access or obstacles to opportunities to add human capital, building on whatever potential individuals may have, as well as the human capital they already possess. For individuals born in higher strata (by income, SES, or other) the gates are mostly open, offering access to a multitude of opportunities. For individuals born in lower strata, the gates are mostly closed so that there are fewer opportunities to amass essential high-quality human capital at a developmentally appropriate stage (Fishkin 2014).

The use of the term "gates" is motivated by the gated communities that have sprung up over the last few decades and are perhaps the most visible aspect of the stratification of opportunity. Children born in such privileged communities have multiple opportunities to develop their human capital, while those born outside of them often have fewer.

However, stratification of opportunity goes far beyond these enclaves of privilege. According to some investigators, over the last few decades, residential segregation by income has remained fairly stable and by race/ethnicity has even declined slightly. Others argue that residential segregation by income has increased. All agree, however, that Blacks and Hispanics remain much more segregated than Whites and Asians (Rugh and Massey 2013; Bischoff and Reardon 2013). Neighborhood differences in income are, in turn, strongly associated with differences in private and public investments in children such as parental attention, school quality, the nature and extent of social networks, and so on (Bischoff and Reardon 2013). These and other factors largely determine which gates are open to some children-and closed to others.

Indeed, it is worth noting that as neighborhoods become more homogeneous with respect to income, so do children's peer groups (Ibid.). This homogeneity carries over to school-whether a neighborhood public school or a private school (parochial or nonsectarian). Increasingly, children find themselves in schools segregated by income as well as by race and ethnicity (Coley and Baker 2013).

Stratification by income also leads to neighborhoods that are more homogeneous with respect to percentages of adults in the labor force or facing long-term unemployment, as well as the types of work engaged in by those who are employed. Such patterns are determined in large part by the type and extent of the human capital that adults bring to the labor market, as well as labor market trends in the kinds of occupations with openings, the salaries and benefits offered, and their locations (Levy and Murnane 2013). At the low end of the spectrum, neighborhoods in which a plurality of adult males either are or have been incarcerated are characterized by high unemployment, high levels of crime, and a lack of positive role models.

As noted at the outset, these trends are driven not only by globalization and the rapid advances in technology but also by interactions among market forces, regulatory decisions, and legislation. Inasmuch as how these trends shape parents' or 
guardians' circumstances, children's opportunities are indirectly—but powerfullyaffected by both macroeconomic factors and general societal trends.

Gaps is a metaphor for the differences among individuals in an age cohort at various points in time in the distributions of human capital. The gaps at the start of full adulthood are a consequence of the dynamic interactions between gates and gaps at each stage of the age span (Sawhill and Karpilow 2014). For example, differences at birth related to various gates being open, ajar, or fully closed lead to gaps as early as they can be measured (see Chap. 8). In turn, those gaps interact with the gates at age 5 (strongly correlated with those at birth) to produce additional gaps by age 14. This process evolves through successive transition points to age 25 and beyond. By age 25 there is great variability in the types and magnitudes of human capital that have been accumulated — and much of that variability can be traced back to individuals' family circumstances at birth and in their formative years.

\section{Gates and Gaps Together}

It is particularly important to understand how gates and gaps interact over time to produce gates and gaps at the next stage. ${ }^{16} \mathrm{~A}$ good example is provided by individuals applying to college at the end of high school. Students from poorer families with weak grades and low test scores face many closed gates: Not only are top-tier colleges and universities out or reach, but when they enroll at community colleges they find that they must take one or more so-called remedial courses, a path that often leads to dropping out before obtaining a degree or certificate. (Bettinger et al. 2013; National Center for Public Policy and Higher Education Special Report 2010). ${ }^{17}$

Sometimes the gates are less obvious. Students coming from families without college experience are less adept at navigating the admissions and financial aid processes and have fewer resources upon which to draw. In fact, a recent study finds that many able, top-scoring minority students coming from lower SES families don't even apply to top-tier colleges, thinking they don't qualify and couldn't afford them if they were accepted (Hoxby and Avery 2013). This problem stems from the lack of a certain kind of social capital, a lack that is amenable to policy intervention (Hoxby and Turner 2014).

One consequence of this dynamic between gates and gaps is relatively homogeneous college campuses, leading to assortative mating and further divergence in

\footnotetext{
${ }^{16}$ The recognition that such dynamic interactions over, say, ages $0-18$ can have powerful effects on the distribution of adult skills is implicit in Brookings Institution, Social Genome Project, and explicit in the work of James Heckman and his associates http://heckmanequation.org/content/ resource/case-investing-disadvantaged-young-children.

${ }^{17}$ The problem of high school graduates going on to tertiary education but required to take one or more noncredit-bearing courses (sometimes designated as remedial or developmental) is more pervasive than one that just concerns students from low-income families. While some studies estimate $35-40 \%$ of students entering college need at least one remedial course, other studies place the estimate as high as $60 \%$.
} 
personal/family trajectories (McClanahan 2014). This divergence is even more pronounced when one looks at the full birth cohort, which includes those who dropped out of high school or completed high school but did not go on for further education or training (see Chap. 7, Fig. 7.13).

Gradients is a metaphor for the strength of the relationships between the dimensions of human capital on the one hand, and various life outcomes on the other. Life outcomes include whether the individual is employed, the nature and remuneration (salary and benefits) of that employment, the possibility of obtaining further education/training, accumulation of wealth, the likelihood of forming stable family units, and having children in the context of those partnerships. The data show that the gradients are typically quite steep; that is, modest differences in human capital can result in substantial differences in outcomes. For example, both the likelihood of full-time employment and the likelihood of having children in the context of a twoparent family are strongly correlated with levels of educational attainment and cognitive skills. Gradients are critical because they account for much of the relative advantage or disadvantage that is passed on to the next generation.

It is worth pointing out that gradients are typically not linear. That is, there are inflection points such that there can be large differences in outcomes for individuals who are close in many facets of human capital. For example, individuals with similar cognitive skills but who differ in whether they obtained a college degree can have very different adult trajectories. On the other hand, differences between inflection points may be less consequential.

In the remainder of the chapter, the gates/gaps/gradients framework will be used to organize some of the voluminous literature concerning the forces and processes driving differences in opportunity, as well as the extent of those differences.

\section{The Dynamics of Inequality}

\section{The Birth Lottery}

For a newborn, whether the gates to different opportunities are open or closed depends very much on family structure and income. Of course, these are mutually dependent and strongly associated with other relevant factors such as parental education, housing, neighborhood characteristics, and school quality. ${ }^{18}$ All these factors have a direct bearing on the investments, private and public, that are made in children.

In general, children born to mothers who are single or in unstable relationships face more closed gates, and the rates of such births vary substantially by mother's race/ethnicity, age, educational attainment, and location. Although nonmarital birth rates are generally declining for all groups, the proportion of all births to unmarried

\footnotetext{
${ }^{18}$ The work of Heckman and his associates is relevant here. For a summary of that work, see Heckman, Case for Investing.
} 
mothers is still very high. For example, as of 2012, the proportion of nonmarital births overall was $40.7 \% .{ }^{19}$ However, the proportions varied considerably by race/ ethnicity: They were $72.6 \%$ for non-Hispanic Blacks, $54 \%$ for Hispanics, and $29 \%$ for non-Hispanic Whites. As one might expect, there is also considerable variation among states in both birth rates and proportions of nonmarital births. ${ }^{20}$

To introduce further nuance to this picture, it appears that less than $20 \%$ of mothers who give birth out of wedlock are truly single; the others are in some form of relationship with the father (Wise 2013). However, these dyads are quite fragile. Follow-up data show that by their fifth birthday, $61 \%$ of these children have experienced the dissolution of the relationship between the parents. By contrast, of children born to married parents, only $18 \%$ have experienced a dissolution by their fifth birthday. ${ }^{21}$

Research supports the criticality of the period from birth to age 5. Not only is brain growth greater than at any other postnatal stage, but also the character of the early learning environment influences patterns of neural growth that in turn are related to the capacity to develop human capital (Fox et al. 2010). ${ }^{22}$ By now there is an extensive research base that documents the conditions that strongly predict whether or not a child thrives in this critical period (Barton and Coley 2013). Some of these conditions typically involve monetary investments. They include pre- and postnatal care, good maternal health, adequate shelter and nutrition, living in a nontoxic environment, appropriate medical and dental care, and high quality day care (when needed). Other conditions involve nonmonetary investments. These include establishing a nurturing relationship, parental attention, socioemotional development, as well as cultivation of early language and numeracy skills.

There is an equally extensive research base that demonstrates that the probability that a child experiences something close to the ideal increases with income and stable family structure. Toward the high end of the income ladder, the gates are mostly open and the child is very likely to thrive; that is, grow up healthy and secure-arriving at school ready both cognitively and socioemotionally. Toward the low end of the ladder, many gates are closed and the child is much less likely to

\footnotetext{
${ }^{19}$ Birth rates are usually calculated as the number of births per 1,000 women in a particular category (e.g., unmarried women aged 15-19). Although nonmarital birth rates have been declining, it is still possible for the proportion of nonmarital births overall to be increasing. The explanation is that the proportion is a function of both category-specific birth rates and the distribution of women among the categories.

${ }^{20}$ For example, teen birth rates varied from a low of $13.8 \%$ in New Hampshire to a high of $42.5 \%$ in New Mexico; Centers for Disease Control 2013. For an explanation of the apparent paradox of declining birth rates and high proportions of nonmarital births, see Wise 2013.

${ }^{21}$ Tach's tabulations from the Fragile Families \& Child Wellbeing Surveys, Waves 3-4, quoted in Smeeding, "Connecting Inequality and Intergenerational Mobility: Looking Ahead, Not Behind" (unpublished presentation).

${ }^{22}$ There is also evidence of continuing neuroplasticity into adolescence. An experiment in Chicago Public Schools focuses on accelerating the development of the math skills of African-American and Latino ninth and 10th graders who are lagging behind their age peers. See David L. Kirp, "Closing the Math Gap for Boys," Sunday Review, New York Times, January 31, 2015.
} 
thrive. Similarly, children who are raised in two-parent families are more likely to find the gates open than are children raised in single-parent families, particularly if the mother is younger and not in a committed relationship (Grannis and Sawhill 2013; Doyle et al. 2009, 1-6; Heckman and Masterov 2007). Whether the gates are mostly open or closed is one manifestation of the constellation of conditions that are typical of higher incomes and/or two-parent families on the one hand, and of lower income and/or single parent families on the other. In both cases, there are powerful implications for future development.

Adequate nutrition can serve as a bellwether indicator of a child's environment. Food insecurity is strongly associated with family structure. Using 2011 survey data, it was found that female-headed households (no spouse) had a $37 \%$ rate of food insecurity, while married couple households had a $14 \%$ rate (Coley and Baker 2013, Fig. 7); both groups saw increases from 2005). Not surprisingly, the relationship between family income and food insecurity is particularly strong. For families with incomes below the poverty level, the rate is $45 \%$, while for families with incomes at least 1.85 times the poverty level, the rate is only $8 \%$.

Poverty is also associated with other obstacles to normal development. For example, studies find that lower income mothers report higher rates of maternal depression than do their higher income peers. A depressed individual is less likely to provide the attention and nurturing that are important to an infant thriving. Moreover, in comparison to children born to more affluent families, children growing up in poorer homes are more likely to be exposed to tobacco smoke and have higher blood levels of lead (Aizer and Currie 2014; Coley and Baker 2013, p. 19).

Many toddlers receive care outside of their own home, either in another home (a relative's or other) or in a center (e.g., early learning centers, nursery schools, and preschools). Among children around 4 years old receiving nonparental day care, poor ones were much more likely to receive low-quality care than nonpoor were (Coley and Baker 2013, Table 8). Not surprisingly, family income is strongly associated with the ability to make private expenditures on behalf of children. Data show that, in 2005-2006, parents in the highest income quintile invested nearly \$8900 in children's enrichment, while those in the lowest quintile invested slightly more than $\$ 1,300$, a ratio of 6.8 . By comparison, in the years $1972-1973$, the ratio was only 4.2 (Duncan and Murnane 2011, Fig. 1.6; see also Kaushal, Magnuson, and Waldfogel 2011).

As noted earlier, the gates to different opportunities tend to be open or closed in tandem. A child born to a young, single mother is more likely to grow up in poverty than one born to parents in a committed, stable relationship. The former is also more likely to live in a stressful environment, less likely to have positive extra-home experiences, such as visits to museums or exhibitions, and to receive beneficial contributions from extended family. It is repeatedly encountering closed gates (or, in other terms, multiple risk factors) that places many children at great disadvantage in their early years and beyond.

Thus, children born to families in different circumstances tend to develop along very different trajectories. Differences in cognitive skills, which are examples of what we here refer to as gaps, appear early on-as early as can be measured (Halle 
et al. 2009, 87-119; for an international perspective, see Bradbury et al. 2013). By the time children enroll in kindergarten, differences in readiness are striking. These results are consistent with the well-known findings of very large differences in vocabulary among kindergarten children from different SES strata (Hart and Risley 1995).

Clearly, the variation in environmental factors documented above is an important contributor. Direct parental investment in children's cognitive development also plays a role. Survey data reveal large differences by SES quintile. The percentage of kindergarteners whose parents read to them every day ranges from $62 \%$ in the highest quintile to $36 \%$ in the lowest. As one might expect, even within quintiles, there are noteworthy differences by race/ethnicity (Coley and Baker 2013).

\section{Beginning School}

The same conditions that are conducive to development from birth to age 5 are important for further development in the elementary grades. To the extent that family circumstances remain reasonably stable, the pattern of gates open or closed at birth is typically replicated at age 5-unless (usually) public interventions are successful in opening those gates that are closed..$^{23}$

Children with more accumulated human capital tend also to have more gates open to new opportunities, such as attending schools that are of higher quality (with respect to such features as teaching staff, safety, and physical plant), more parental involvement in schooling, more extracurricular experiences, and benefiting from good nutrition and adequate medical/dental care. Children with lesser amounts of accumulated human capital are more likely to attend lower quality schools with fewer extracurricular activities. They are also more likely to suffer from health problems (e.g., asthma) and medical/dental problems that result in increased school absences and less engagement when in school.

Children starting behind in K-1 have difficulty catching up. Many are not reading on grade level by the end of grade 3-they are still "learning to read" rather than "reading to learn." Studies show that students who enter kindergarten with little to no text comprehension skills are far behind peers with average or high text comprehension skills, and this gap continues to widen through third grade. A similar trend is found in mathematics - a child entering kindergarten who does poorly in basic numbers skills will only fall further and further behind peers by third grade (Foster and Miller 2007; Bodovski and Farkas 2007).

Of course, an important mission of schools is to close the gaps that are evident on the first day of class. But the schools attended by poor children-many if not most of whom are on the wrong side of the gap-are often ill-equipped to do so. Teachers in these schools are more likely to have fewer years of experience and less likely to have the requisite qualifications than teachers in schools serving more

${ }^{23} \mathrm{~A}$ discussion of such interventions is beyond the scope of this chapter. 
affluent students. Moreover, those schools experience greater instability, with respect to both staff and students, so that there are fewer opportunities for students to receive coherent, systematic instruction.

Of course, peer interactions are an important component of schooling. In parallel with increased residential segregation, over the past two decades schools have become more segregated both by income and by race/ethnicity. As commentators have noted, "While the average White student attends a school where poor students account for a quarter to a third of enrollment, the typical Black or Hispanic student attends a school where nearly two-thirds of their peers are low-income" (Orfield et al. 2012, quoted in Coley and Baker 2013, p. 25). They also point out that "38 and $43 \%$ of Black and Hispanic students, respectively, attended schools where $90-100 \%$ of students were minorities."

As poor and minority students make their way through school, they are more likely to experience suspensions, be required to repeat a grade and, eventually, drop out before completing high school. In 2009, students from the lowest family income quintile were about five times more likely to drop out than students from the highest quintile were. ${ }^{24}$ Thus, by late adolescence or early adulthood, the gaps in cognitive skills are substantial and likely the result of the interaction of earlier gaps and current school quality. Presumably, this is one of the mechanisms by which later gaps are still strongly associated with family background.

Another kind of gap relates to flexibility and resilience. Those who have had the benefit of open gates - and have taken advantage of the opportunities offered them - find themselves on the right side of the gaps related to flexibility (cognitive skills, maturity, etc.) in adapting to new circumstances or demands. They also have the capacity to recover from setbacks. As an example, poor students who enroll in postsecondary programs are more likely to accumulate college debts that are large in relation to family income and to carry that debt for a long time, particularly if they leave without a degree or a marketable certificate. As a consequence, they will lack the flexibility to respond to job opportunities that require moving and incurring further expenses. On the other hand, students from more advantaged backgrounds are less likely to accumulate substantial debt, more likely to graduate, and are able to call on family resources to take advantage of opportunities, such as unpaid internships, that demand further expenditures..$^{25}$

\footnotetext{
${ }^{24}$ For suspensions, see report of U.S. Department of Education 2014; For dropouts, see SES Indicator, "Poverty and High School Dropouts," blog entry by Russell W. Rumberger, American Psychological Association, May 2013, http://www.apa.org/pi/ses/resources/indicator/2013/05/ poverty-dropouts.aspx, and references therein. See also Kearney and Levine (2014).

${ }^{25}$ Suzanne Mettler, "College, the Great Unleveler," New York Times, March 1, 2014. For a somewhat different view of college debt, see Chingos 2014.
} 


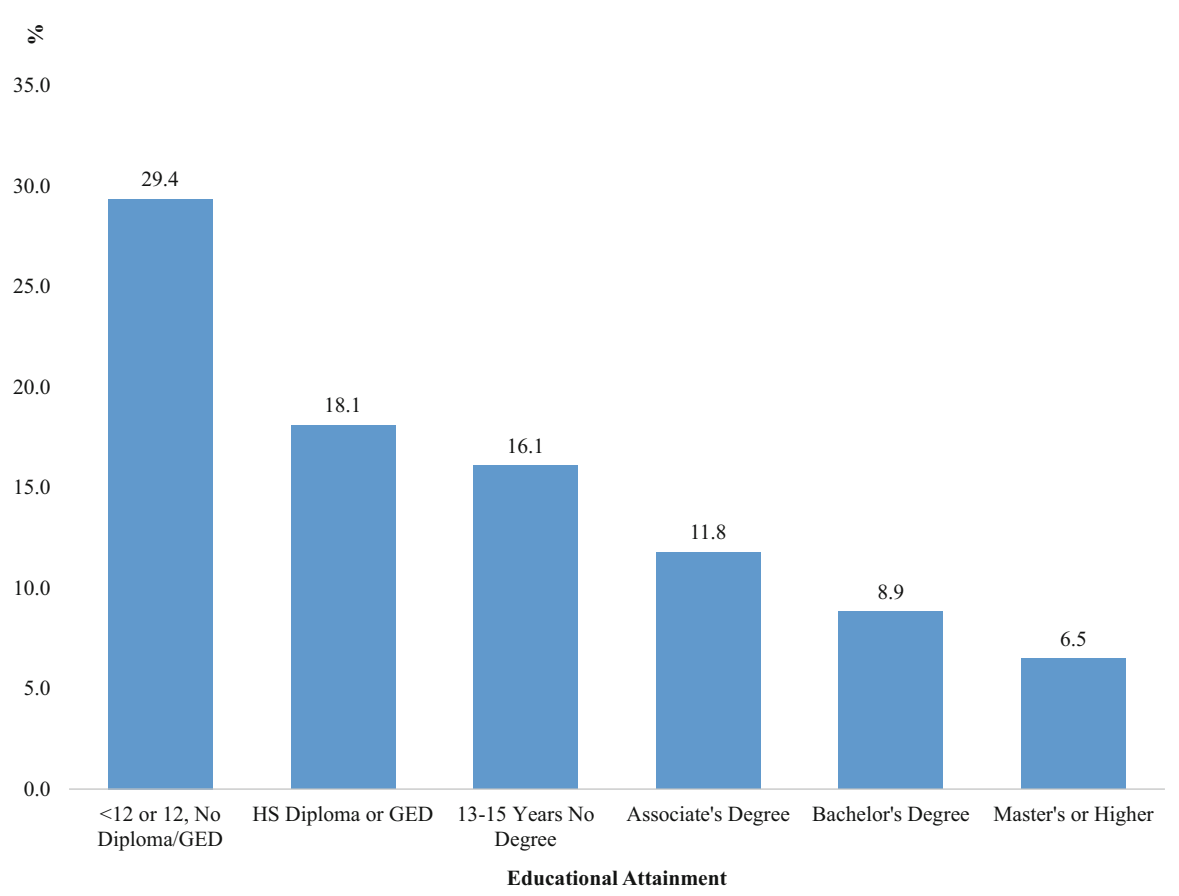

Fig. 5.6 Underutilization rates among U.S. workers (16 and over) by educational attainment, January 2012-August 2013 averages (in \%) (see Chap. 7, Fig. 7.12)

\section{Gradients}

As noted earlier, the term "gradients" denotes the relationships between accumulated human capital and outcomes in adulthood. One oft-cited example is the relationship between unemployment and educational attainment. During the period from January 2013 to August 2014, the unemployment rate for high school dropouts with no GED stood at $13.9 \%$, with the rates decreasing with increasing levels of educational attainment; for those with master's degrees or higher, the rate was only $2.9 \%$ (see Chap. 7, Fig. 7.2). Unfortunately, the problem is far worse than first appears. As some labor economists argue, one must also take into account underemployment and hidden unemployment. ${ }^{26}$ They define the labor underutilization rate as the sum of the unemployment, underemployment, and hidden unemployment rates. Figure 5.6 shows the labor underutilization rates as a function of educational attainment. The rates range from nearly $30 \%$ for those with no high school diploma and no GED to $6.5 \%$ for those with a master's degree or above (see Khatiwada and Sum, Chap. 7, Fig. 7.12). Even among those with full-time employment, there is a

\footnotetext{
${ }^{26}$ Underemployment refers to individuals who are working fewer hours than they desire. Hidden unemployment refers to individuals who are jobless and not actively seeking work, but indicated that they wanted to work.
} 
Table 5.2 Comparisons of the unemployment rates of U.S. adults 16 and older by educational attainment, 2000 and 2012-2013 (in \%) (Sum presentation 2014)

\begin{tabular}{l|l|l|l}
\hline \multirow{2}{*}{ Educational Attainment } & $($ A $)$ & $($ B $)$ & $($ C) \\
\cline { 2 - 4 } & 2000 & $2012-2013$ & Percentage point change \\
\hline$<12$ or 12, no diploma or GED & 8.6 & 14.9 & +6.3 \\
\hline H.S. diploma or GED & 4.4 & 9.8 & +5.4 \\
\hline 13-15 years, no degree & 3.5 & 8.4 & +4.9 \\
\hline Associate's degree & 2.4 & 6.2 & +3.8 \\
\hline Bachelor's degree & 2.0 & 4.7 & +2.7 \\
\hline Master's or higher degree & 1.4 & 3.3 & +1.9 \\
\hline All $(16+)$ & 4.0 & 8.0 & +4.0 \\
\hline
\end{tabular}

steep gradient in weekly earnings with respect to educational attainment. In 2009, the ratio in weekly earnings for individuals (aged 25 or more) with a bachelor's degree was 1.64 relative to those with a high school diploma and 2.26 relative to high school dropouts. The ratios were quite similar for comparisons both among men and among women. ${ }^{27}$

There are similarly steep gradients on social outcomes, broadly conceived. For example, in 2009, the percentage of mothers who were never married ranged from $20.1 \%$ for those with less than 12 years of education to only $3.3 \%$ for those with 18 or more years of education. ${ }^{28}$ Not surprisingly, in 2010 , the percentage of births to unmarried women stood at nearly $50 \%$ for those with lower education and at $10 \%$ for those with higher education (Ibid.). These differences by education level have widened substantially over the last three decades.

There is considerable evidence that workplace-related gradients have been getting steeper over time as well. As Table 5.2 shows, from 2000 to 2012-2013, the unemployment rate rose for all levels of educational attainment, but the percentage point increase was greater for those with lower educational attainment. ${ }^{29}$ Concomitantly, Table 5.3 shows that for individuals with full-time employment, those with lower educational attainment lost ground absolutely (in inflation-adjusted dollars) from 1979 to 2009; only those with bachelor's degrees or higher gained ground (Chap. 7). Consequently, wage ratios increased substantially over the period. For example, the ratio for those holding a bachelor's degree to those holding a high school diploma went from 1.32 to 1.64 , an increase of almost $25 \%$.

These patterns appear to be the result of a confluence of several forces and trends. Over the last two decades, technology has enabled many jobs to be off-shored, made obsolete, or changed them so dramatically that many fewer workers with different

\footnotetext{
${ }^{27}$ Andrew Sum, personal communication, May 2, 2014.

${ }^{28}$ Timothy Smeeding, "Connecting Inequality and Intergenerational Mobility: Looking Ahead, Not Behind" (unpublished PowerPoint presentation. Madison, WI: Institute for Research on Poverty, 2014).

${ }^{29}$ Current Population Survey monthly household surveys [public use files 2000 and January 2012-August 2013]. Data compiled by the Center for Labor Market Studies, Northeastern University.
} 
Table 5.3 Wages for full-time employment by educational attainment, 1979-2009 (Sum presentation 2014)

\begin{tabular}{l|l|l|l|l}
\hline & (A) & (B) & (C) & (D) \\
\cline { 2 - 5 } Educational attainment & 1979 & 2009 & $\begin{array}{l}\text { Absolute change, } \\
1979-2009\end{array}$ & $\begin{array}{l}\text { Percent change, } \\
1979-2009\end{array}$ \\
\hline High school dropouts & 696 & 500 & -196 & $-28 \%$ \\
\hline High school graduates & 869 & 716 & -153 & $-18 \%$ \\
\hline $\begin{array}{l}\text { Some college, including } \\
\text { associate degree }\end{array}$ & 942 & 835 & -107 & $-11 \%$ \\
\hline Bachelor's degree & 1086 & 1200 & +114 & $+10 \%$ \\
\hline Master's or higher degree & 1170 & 1535 & +365 & $+31 \%$ \\
\hline H.S. graduate/H.S. dropout & 1.25 & 1.43 & +.18 & \\
\hline Some college/H.S. graduates & 1.08 & 1.17 & +.09 & \\
\hline $\begin{array}{l}\text { B.A. degrees/H.S. graduates } \\
\text { Master's or higher/H.S. }\end{array}$ & 1.25 & 1.68 & +.43 & \\
graduates & 1.35 & 2.14 & +.79 & \\
\hline
\end{tabular}

skills are required, as is the case with advanced manufacturing. ${ }^{30}$ Some economists argue that technology, in various forms, leads to a "winner take all" economy that produces greater inequality. ${ }^{31}$ The combination of technology, globalization, and the broad deregulation of industry that began in the 1980s, with the specter of offshoring in the background, has exerted a downward pressure on wages in the many sectors that are now characterized by both fewer jobs and more job seekers. The decline of private sector unions, along with differences between states in "right to work" laws, has reduced the bargaining power of local workforces. While the decline of the buying power of the minimum wage contributes to the decline of those at the low end of the skill distribution, there is generally an upward pressure on wages for those who possess specialized skills that are scarce and in demand. The driver of this divergence is sometimes referred to as "skill-biased technological change."

More ominously, the "second IT revolution" will feature even faster computers with more powerful forms of artificial intelligence that will automate, partially or fully, many jobs that are now considered to be more skilled (Brynjolfsson and McAfee 2014, 34-37). Even today the new workplace rewards high-level cognitive skills, flexibility, and the capacity to continuously upgrade skills as job requirements change (Levy and Murnane 2013). Moreover, individuals who have found a good place in the new economy are more likely to be offered training and educational opportunities that enable them to keep pace with workplace changes. Those who are in low-wage, low-skill occupations rarely have such opportunities and face many obstacles in trying to obtain new skills on their own (e.g., through enrollment in a community college or vocational training center).

\footnotetext{
${ }^{30}$ Goldin and Katz 2008.

${ }^{31}$ Alan Krueger, "Land of Hope and Dreams: Rock and Roll, Economics, and Rebuilding the Middle Class" (remarks, Rock and Roll Hall of Fame, Cleveland, June 12, 2013).
} 


\section{Why Is Expanding Opportunity Important?}

Employing the gates/gaps/gradients framework helps us understand how initial differences in opportunity can be magnified over time, resulting in wide disparities in accumulated human capital and increasing inequality in life outcomes that, in turn, contribute to greater differences in opportunity in the next generation. This cycle leads to what might be termed an accelerated accumulation of advantage (or disadvantage).${ }^{32}$ An America that offers opportunity to all, we noted at the outset, has been an enduring belief and contributed to the strength of this country-in part by drawing immigrants from all over the world searching for a better life for themselves and for their children. That this was never the case for everyone, and that it may be less true today than many imagine, in no way diminishes its importance and the obligation to promote its resurgence.

That obligation has many facets. It is a moral obligation, particularly to the children born to disadvantage who, nonetheless, deserve a decent chance to realize their potential. Denying them that opportunity is not just a betrayal of America's promise but does a disservice to us all-in greater social costs and lower overall economic growth (Stiglitz 2012). ${ }^{33}$ In fact, there is good empirical evidence that greater inequality and the concomitant disparities in opportunity are associated with poorer health and less general satisfaction for everyone, even those on the top rungs of the ladder (Wilkinson and Pickett 2010; Sanger-Katz 2015).

There is some debate about whether increasing inequality portends lower intergenerational mobility (IGM) (Winship and Schneider 2014; Jerrim and Macmillan 2014). Although cross-nationally there is a strong association between greater income inequality and lower IGM, it is less clear whether that pattern holds within a country over time. Recent research suggests that in the U.S., IGM has remained steady, though at rather low levels. IGM appears to be particularly low at the extremes of the income distribution (Chetty et al. 2014a; Corak 2013). However, it will take another 15-20 years for the impact of the recession of 2007-2010 on IGM to fully play itself out.

Irrespective of its consequences for IGM, the increasing separation between rungs of the income ladder has immediate implications for the lives of all. On the one hand, many goods, such as televisions and cell phones, have become both cheaper and better. Indeed, some argue that, from an historical perspective, the percentage of the population that is poor has decreased markedly (Jencks 2015). On the other hand, individuals and families at the low end are spending a greater proportion

\footnotetext{
${ }^{32}$ For a comprehensive review of cumulative advantage, see DiPrete and Eirich 2006.

${ }^{33}$ See interview with Christopher Jencks for a different view. Eduardo Porter, "Income Equality: A Search for Consequences," New York Times, March 25, 2014, http://www.nytimes.com/2014/03/26/ business/economy/making-sense-of-income-inequality.html. Also see interview with Lane Kenworthy. Eduardo Porter, "Q\&A: A Sociologist on Inequality," New York Times, March 25, 2014. http://economix.blogs.nytimes.com/2014/03/25/qa-a-sociologist-on-inequality/.
} 
of their disposal income on such necessities as food, rent, utilities, and transportation that relate directly to their ability to invest in themselves and their children. ${ }^{34}$

We appear to be moving from a market economy to a market society, where everything has a price. When this extends beyond goods and services to social practices, it changes social relations and the meanings we attach to those relations (Sandel 2012). More prosaically, but no less importantly, this can be seen in the role of money in political campaigns. With the recent Supreme Court decisions striking down campaign finance restrictions, the influence of wealthy contributors to political campaigns will only grow.

Increasing inequality, in conjunction with other trends and developments, helps to shape civil society and the democratic polity. As we become more segregated by income and education, we typically have less empathy for those with whom we have little contact (Friedman 2005). Such polarization necessarily undermines the notion of a shared future. When and if a large proportion of the population loses faith in the fairness of the social order and the extant political arrangements, then the stability that depends on the "consent of the governed" is threatened. Unfortunately, there is good evidence that differences in opportunity continue to increase over time and that many people have become disengaged from both civil society and the political process (Murray 2012). Looking ahead to the next generation, Putnam (2015) argues that, among high school students and young adults, there is an increasing divergence in this respect between those at the high end of the socioeconomic scale and those at the low end.

\section{Moving Forward}

The critical question is whether the dynamics of increasing divergence in opportunities and in life outcomes are self-correcting or self-reinforcing. More simply, was the pattern of shared prosperity seen in the three decades following World War II an anomaly?

Employing a vast trove of historical data, the French economist Thomas Piketty argues that increasing inequality in wealth is the inexorable outcome of a market economy in which, over the long run, the returns to capital outpace the returns to labor and, consequently, result in the increasing concentration of wealth and political power. This trend, he avers, can only be held in check by government action. Such actions should include a global wealth tax as well as greater investments in education and training (Piketty 2014).

\footnotetext{
${ }^{34}$ Planet Money (NPR blog), "How the Poor, the Middle Class and the Rich Spend Their Money," blog entry by Jacob Goldstein, August 1, 2012, http://www.npr.org/blogs/money/ 2012/08/01/157664524/how-the-poor-the-middle-class-and-the-rich-spend-their-money; Real Time Economics (Wall Street Journal blog), "How Rich and Poor Spend (and Earn) Their Money," April 6, 2015, http://blogs.wsj.com/economics/2015/04/06/how-the-rich-and-poor-spend-andearn-their-money/.
} 
His diagnosis is supported by the economist Alan Krueger, who decries the "erosion of the institutions and practices that supported shared prosperity." He argues that private industry has to take the lead in righting this balance and government's responsibility is to set the conditions for that recommitment to the common good. This seems a bit weak - and he does end with a list of more forceful interventions, including an increase in the minimum wage, financial reform, income tax reform, and greater infrastructure investment..$^{35}$

To be sure, some economists argue that this phenomenon is a natural outgrowth of human variation: Starting with a perfectly equal society, individual differences in talent, energy, and motivation, as well as random shocks, would inexorably lead to an unequal society; moreover, this inequality, however extreme, does not signal unfairness or inefficiency (Mankiw 2013). This view leads to a recommendation of minimal policy interventions. Stiglitz, who is quoted at the outset of this chapter, takes a less benign view: He sees increasing inequality as a signal of market inefficiencies, such as rent-seeking (trying to obtain economic gain without any reciprocal benefit to society), and argues that those with greater resources are in an ever better position to influence laws and regulations to preserve and strengthen these advantages, for their benefit, their families, and associates (Stiglitz 2012).

If one adopts the less sanguine view, then there are certainly formidable barriers to countering the self-reinforcing dynamics of inequality of opportunity. A polarized central government is unlikely to take bold action, especially in light of the unavoidable uncertainties involved in projecting current trends into the future. (This situation is much like the one confronting those who argue for strong action on climate change.) Indeed, budget plans from the House of Representatives prescribe scaling back some of the supports now provided to the poor. Yet at the same time, the Affordable Care Act acts to extend medical insurance to millions of individuals who have done without, although efforts continue to derail or scale it back.

One can certainly hope that some segments of private industry will take the lead. Here there is certainly a mixed picture. On the one hand, the finance industry spends millions on protecting such benefits as the "carried interest" provision in the tax code or on weakening the financial regulations spurred by the Dodd-Frank Act. ${ }^{36}$ For the most part, large retailers and fast food chains are resisting an increase in the minimum wage, even though its real purchasing power has plummeted since it was last raised..$^{37}$

On the other hand, there is some evidence that a few corporations are taking a broader view of their responsibilities - not only to their shareholders and customers but also to their employees, the communities in which they are located, and even to

\footnotetext{
${ }^{35}$ Krueger, "Land of Hope."

${ }^{36}$ Paul Krugman, “Obama's Other Success,” New York Times, August 4, 2014, http://www.nytimes. com/2014/08/04opinion/paul-krugman-dodd-frank-financial-reform-is-working.html/.

${ }^{37}$ On February 19, 2015, Doug McMillon, Walmart President and CEO, announced a program of increases in the minimum wage for current and new associates, as well as for department managers. About a month later, McDonald's followed suit with a wage increase for employees in its corporate-run stores.
} 
society at large. That broader view goes beyond the traditional "bottom line" to consideration of community stability and environmental stewardship (Googins, Mirvis, and Rochlin 2007; Freeland presentation to Opportunity in America panel 2014). At present it is hard to determine whether this movement toward sustainable capitalism will prove to be long lasting and whether it will have any effect on the dynamics of inequality.

In the search for viable policies and the strategies to build consensus around them, it is necessary to consider some further complications. For example, the family circumstances that play such a critical role in the access to opportunity are not just determined by the impersonal forces we have been discussing. They are also a product of individual choices, sometimes poor ones. To what extent can and should government intervene, at least on behalf of children, to compensate for those choices, for insufficient private investment in the children, or even parental neglect? There can be reasoned disagreement on government's responsibility.

At the same time there is considerable evidence that early interventions, say between birth and age 3, if effective, can yield benefit-to-cost ratios substantially above 1 and considerably greater than those for later interventions can. Moreover, it appears that those early interventions can enhance the effects of later interventions in a virtuous cycle (particularly if they target both cognitive and noncognitive skills) with important implications for later labor market success (Heckman, Case for Investing). ${ }^{38}$

Another complication arises because the distribution of opportunity is "lumpy"it varies substantially by location, as well as by demographic characteristics such as race-ethnicity, immigration status, prison record, and so on. Presumably, the conjunction of these factors can either mitigate or exacerbate access to opportunity. For example, recent data indicate that other things being equal, Blacks are more likely to have lost ground in the distributions of income and wealth during the recession (for a general discussion of race in America, see Orfield 2014).

Over the last decade, certain areas have become hubs of the new economy with a high concentration of well-paying jobs, while others stagnate or decline. For the former, there are spillover effects, so that even those further down the skills ladder derive some benefit from being located in those areas (Acs 2013; Moretti 2013). Although intergenerational mobility may well be stable (or stagnant) overall, it varies very substantially by location. For example, recent work shows that, roughly speaking, for children growing up in below-median income families, upward mobility is highest in the Midwest, lowest in the Southeast, and moderate at the coasts (Chetty 2014b).

Thus, it appears that a viable policy strategy will have to comprise multiple initiatives at various governmental levels, with serious attempts to bring the resources of both the for-profit and nonprofit sectors to bear on the problem. Although the dynamics underlying the current situation are complex, they are not beyond under-

\footnotetext{
${ }^{38}$ As results from the Brookings Institution Social Genome Project make clear, real impact on human capital accumulation results from systematic interventions throughout the a child's development.
} 
standing or mitigation. As one commentator put it: "Rising inequality is a trend, but it is one we have helped create and one we can still change." ${ }^{39}$

Open Access This chapter is distributed under the terms of the Creative Commons AttributionNoncommercial 2.5 License (http://creativecommons.org/licenses/by-nc/2.5/) which permits any noncommercial use, distribution, and reproduction in any medium, provided the original author(s) and source are credited.

The images or other third party material in this chapter are included in the work's Creative Commons license, unless indicated otherwise in the credit line; if such material is not included in the work's Creative Commons license and the respective action is not permitted by statutory regulation, users will need to obtain permission from the license holder to duplicate, adapt or reproduce the material.

\section{References}

Acemoglu, Daron, and David Autor. 2012. "What does human capital do?", Review of The race between education and technology, by Claudia Goldin and Lawrence F. Katz. Journal of Economic Literature 50(2): 426-463.

Acs, Gregory. 2013. The Moynihan report revisited. Washington, DC: Urban Institute. http://www. urban.org/UploadedPDF/412839-The-Moynihan-Report-Revisited.pdf.

Aizer, Anna, and Janet Currie. 2014. The intergenerational transmission of inequality: Maternal disadvantage and health at birth. Science 344(6186): 856-861.

Alexander, Karl, Doris Entwistle, and Linda Olson. 2014. The long shadow: Family background, disadvantaged urban youth, and the transition to adulthood. New York: Russell Sage.

Autor, David. 2014. Skills, education, and the rise of earnings inequality among the 'other 99 percent'. Science 344(6186): 843-851.

Barton, Paul, and Richard Coley. 2013. Parsing the achievement gap, II. Princeton: Policy Information Center, Educational Testing Service. http://www.ets.org/Media/Research/pdf/ PICPARSINGII.pdf

Bettinger, Eric, Angela Boatman, and Bridget Terry Long. 2013. Student supports: Developmental education and other academic programs. The Future of Children 23(1): 93-115. http://futureofchildren.org/publications/journals/article/index.xml?journalid=79\&articleid=582.

Bischoff, Kendra, and Sean F. Reardon. 2013. Residential segregation by income, 1970-2009. New York: Russell Sage.

Black, Sandra E., and Paul J. Devereux. 2010. Recent developments in intergenerational mobility (NBER Working Paper 15889). Cambridge, MA: National Bureau of Economic Research. http://www.nber.org/papers/w15889.

Blanden, Jo. 2013. Cross-country rankings in intergenerational mobility: A comparison of approaches from economics and sociology. Journal of Economic Surveys 27(1): 38-73.

Bodovski, Katerina, and George Farkas. 2007. Mathematics growth in elementary school: The roles of beginning knowledge, student engagement, and instruction. Elementary School Journal 108(2): 115-130.

Bradbury, Bruce, Corak Miles, Waldfogel Jane, and Washbrook, Elizabeth. 2013. Inequality in early childhood outcomes. In From parents to children: The intergenerational transmission of disadvantage, ed. John Ermisch, Markus Jantii, and Timothy Smeeding, 87-119. New York: Russell Sage.

\footnotetext{
${ }^{39}$ David Leonhardt, "Inequality Has Been Going On Forever ... but That Doesn't Mean It's Inevitable," New York Times magazine, May 2, 2014, http://www.nytimes.com/2014/05/04/magazine/inequality-has-been-going-on-forever-but-that-doesnt-mean-its-inevitable.html.
} 
Brody, Gene H., Yu. Tianyi, Chen Edith, E. Miller Gregory, M. Kogan Steven, and R.H. Beach Steven. 2013. Is resilience only skin deep? Rural African-Americans' socioeconomic statusrelated risk and competence in preadolescence and psychological adjustment and allostatic load at age 19. Psychological Science 24(7): 1285-1293.

Brookings Institution. 2013. Social genome project: Mapping pathways to the middle class. Washington, DC: Brookings Institution (April). http://www.brookings.edu/ /media/Centers/ ccf/SGP_overview.pdf.

Brynjolfsson, Erik, and Andrew McAfee. 2014. The second machine age: Work, progress, and prosperity in a time of brilliant technologies. New York: W.W. Norton.

Centers for Disease Control. 2013. Births: Final data for 2012, by Joyce A. Martin, Brady E. Hamilton, Michelle J. K. Osterman, Sally C. Curtin, and T. J. Matthews, 62(9) (National Vital Statistics Reports, December 30). http://www.cdc.gov/nchs/data/nvsr/nvsr62/nvsr62_09. pdf.

Chetty, Raj, Nathaniel Hendren, Patrick Kline, and Emmanuel Saez. 2014a. Is the United States still a land of opportunity? Recent trends in intergenerational mobility, NBER working paper 19843. Cambridge, MA: National Bureau of Economic Research.

Chetty, Raj, Nathaniel Hendren, Patrick Kline, and Emmanuel Saez. 2014b. Where is the land of opportunity? intergenerational mobility in the US, VoxEU.org. Center for Economic Policy Research. http://www.voxeu.org/article/where-land-opportunity-intergenerational-mobility-us.

Chingos, Matthew M. 2014. Why student loan rhetoric doesn't match the facts (Brown Center, Chalkboard 75). Washington, DC: Brookings Institution, July 17. http://www.brookings.edu/ research/papers/2014/07/17-student-loan-rhetoric-chingos.

Coley, Richard, and Bruce Baker. 2013. Poverty and education: Finding the way forward. Princeton: Policy Information Center, Educational Testing Service. http://www.ets.org/s/ research/pdf/poverty_and_education_report.pdf.

Corak, Miles. 2013. Income inequality, equality of opportunity, and intergenerational mobility. Journal of Economic Perspectives 27(3): 79-102.

Cowen, Tyler. 2013. Average is over: Powering America beyond the age of the great stagnation. New York: Dutton.

Current Population Survey monthly household surveys [public use files, 2000 and January 2012_ August 2013]. Data compiled by the Center for Labor Market Studies, Northeastern University.

DiPrete, Thomas A., and Gregory M. Eirich. 2006. Cumulative advantage as a mechanism for inequality: A review of theoretical and empirical developments. Annual Review of Sociology 32: 271-297.

Doyle, Orla, Colm P. Harmon, James J. Heckman, and Richard E. Tremblay. 2009. Investing in early human development: Timing and economic efficiency. Economics and Human Biology, 7(1) (March). doi: 10.1016/j.ehb.2009.01.002.

Duncan, Greg J., and Richard J. Murnane. 2011. Introduction: The American dream, then and now. In Whither opportunity: Rising inequality, schools, and children's life chances, ed. Greg J. Duncan and Richard J. Murnane, 3-23. New York: Russell Sage Foundation/Spencer Foundation.

Fishkin, Joseph. 2014. Bottlenecks: A new theory of equal opportunity. New York: Oxford University Press.

Foster, Wayne A., and Merideth Miller. 2007. Development of the literacy achievement gap. Language, Speech, and Hearing Services in Schools 38: 173-181. doi:10.1044/0161-1461(2007/018).

Fox, Sharon E., Pat Levitt, and Charles A. Nelson III. 2010. How the timing and quality of early experiences influence the development of brain architecture. Child Development 81: 28-40.

Friedman, Benjamin M. 2005. The moral consequences of economic growth. New York: Knopf.

Goldin, Claudia, and Lawrence F. Katz. 2008. The race between education and technology. Cambridge: Harvard University Press.

Goodman, Madeline J., Anita M. Sands, and Richard J. Coley. 2015. America's skills challenge: Millennials and the future. Princeton: ETS Center for Research on Human Capital and Education, Educational Testing Service. 
Googins, Bradley K., Philip H. Mirvis, and Steven A. Rochlin. 2007. Beyond good company: Next generation corporate citizenship. New York: Palgrave McMillan.

Grannis, Kerry Searle, and Isabel V. Sawhill. 2013. Improving children's life chances: Estimates from the Social Genome Model. Social Genome Project Research (49). Washington, DC: Brookings Institution.

Halle, Tamara, Nicole Forry, Elizabeth Hair, Kate Perper, Laura Wandner, Julia Wessel, and Jessica Vick. 2009, June. Disparities in early learning and development: Lessons from the early childhood longitudinal study-Birth Cohort (ECLS-B). Washington, DC: Council of Chief State School Officers and Child Trends. http://www.childtrends.org/wp-content/ uploads/2013/05/2009-52DisparitiesELExecSumm.pdf.

Hart, Betty, and Todd Risley. 1995. Meaningful differences in the everyday experiences of young American children. Baltimore: Brooks Publishing.

Heckman, James J. (n.d.). The case for investing in disadvantaged young children. The Heckman Equation. http://heckmanequation.org/content/resource/case-investing-disadvantaged-youngchildren.

Heckman, James J., and Dimitriy V. Masterov. 2007. The productivity argument for investing in young children. Applied Economic Perspectives and Policy 29(3): 446-493. http://aepp.oxfordjournals.org/content/29/3/446.extract.

Hoxby, Caroline, and Christopher Avery. 2013. The missing "One-Offs": The hidden supply of high-achieving, low-income students. Washington, DC: Brookings Papers on Economic Activity (Spring). http://www.brookings.edu/ /media/projects/bpea/spring\%202013/2013a_ hoxby.pdf.

Hoxby, Caroline, and Sarah Turner. 2014. Expanding college opportunities for high-achieving, low income students. SIEPR Discussion Paper 12-014. Stanford: Stanford Institute for Economic Policy Research.

Jencks, Christopher. 2015. The war on poverty: Was it lost? New York review of books, April 2.

Jerrim, John, and Lindsey Macmillan. 2014. Income inequality, intergenerational mobility and the Great Gatsby curve: Is education the key? London: Institute of Education, University of London.

Kaushal, Neeraj, Katherine Magnuson, and Jane Waldfogel. 2011. How is family income related to investments in children's learning? In Whither opportunity: Rising inequality, schools, and children's life chances, ed. Greg J. Duncan and Richard J. Murnane, 187-206. New York: Russell Sage Foundation/Spencer Foundation.

Kearney, Melissa Schettini, and Phillip B. Levine. 2014. Income inequality, social mobility, and the decision to drop out of high school, NBER Working Paper 20195. Cambridge, MA: National Bureau of Economic Research. http://www.nber.org/papers/w20195.

Keeley, Brian. 2007. Human capital: How what you know shapes your life. Paris: OECD Publishing. doi:10.1787/9789264029095-en.

Levy, Frank, and Richard Murnane. 2013. Dancing with robots: Human skills for computerized work. Washington, DC: Third Way. http://content.thirdway.org/publications/714/DancingWith-Robots.pdf.

Mankiw, Gregory W. 2013. Defending the $1 \%$. Journal of Economic Perspectives 27(3): 21-34.

McClanahan, Sara. 2014. Diverging destinies: How children are faring under the second demographic transition. Demography 41a(4): 607-627. https://muse.jhu.edu/journals/demography/ v041/41.4mclanahan.pdf.

Moretti, Enrico. 2013. The new geography of jobs. Boston: Mariner Books.

Murray, Charles. 2012. Coming apart: The state of White America 1960-2010. New York: Crown Forum.

National Center for Public Policy and Higher Education Special Report. 2010. Beyond the Rhetoric: Improving college readiness through coherent state policy. http://www.highereducation.org/reports/college_readiness/index.shtml.

Noah, Timothy. 2013. The great divergence: America's growing inequality crisis and what we can do about it. London: Bloomsbury Press. 
OECD (Organisation for Economic Co-operation and Development). 2013. First results from the survey of adult skills. Paris: OECD Skills Studies, OECD Publishing. doi:10.1787/9789264204256-en.

Orfield, Gary. 2014. A new civil rights agenda for American education. Educational Researcher 43(6): 273-292.

Orfield, Gary, John Kucsera, and Genevieve Siegl-Hawley. 2012. E pluribus ... separation: Deepening double segregation for more students. Los Angeles: The Civil Rights Project, as cited in Coley and Baker, Poverty and Education.

Pellegrino, James W., and Margaret L. Hilton (eds.). 2012. Education for life and work: Developing transferable knowledge and skills in the 21st century. Washington, DC: National Academies Press.

Piketty, Thomas. 2014. Capital in the 21st century. Cambridge, MA: Harvard University Press.

Putnam, Robert. 2015. Our kids: The American dream in crisis. New York: Simon \& Schuster.

Reardon, Sean F. 2011. The widening achievement gap between the rich and the poor: New evidence and possible explanations. In Whither opportunity: Rising inequality, schools, and children's life chances, ed. Greg J. Duncan and Richard J. Murnane, 91-116. New York: Russell Sage Foundation/Spencer Foundation.

Rugh, Jacob S., and Massey, Douglas S. 2013. Segregation in post-civil rights America: Stalled integration or end of the segregated century? The DuBois Review: Social Science Research on Race. doi:10.1017/S1742058X13000180.

Sandel, Michael J. 2012. What money can't buy: The moral limits of markets. New York: Farrar, Strauss, and Giroux.

Sanger-Katz, Margot. 2015. How income inequality can be bad for your health. New York Times, March 31. http://www.nytimes.com/2015/03/31/upshot/income-inequality-its-also-bad-foryour-health.html?abt=0002\&abg=1.

Sawhill, Isabel V., and Quentin Karpilow. 2014. How much could we improve children's life chances by intervening early and often?, CCF Brief 54. Washington, DC: Brookings Institution.

Stiglitz, Joseph. 2012. The price of inequality. New York: W. W. Norton.

Thompson, Derek. 2012. A giant statistical round-up of the income inequality crisis in 16 charts, Atlantic, December 12. http://www.theatlantic.com/business/ archive/2012/12/a-giant-statistical-round-up-of-the-income-inequality-crisis-in-16charts/266074/.

U.S. Department of Education, Office for Civil Rights, Civil Rights Data Collection of 2011-2012, Washington, DC: 2014 (March 21). http://www2.ed.gov/about/offices/list/ocr/whatsnew. html\#2014.

Wilkinson, Richard G., and Kate Pickett. 2010. The spirit level: Why greater equality makes societies stronger. New York: Bloomsbury Press.

Winship, Scott, and Donald Schneider. 2014. The collapse of the Great Gatsby curve. e21, February 3. http://www.economics21.org/research/collapse-great-gatsby-curve.

Wise, Tim. 2013. Explaining conservative deception about out-of-wedlock births in the Black community. BlackVisions.org, Aug. 3. http://www.blackvisions.org. 